\title{
Religious Ideology, Race, and Health Care Policy Attitudes
}

\section{R. Khari Brown (D) \\ Wayne State University}

\section{Angela Kaiser \\ Oakland University}

\begin{abstract}
Using two national general population and one clergy survey, we examined racial differences in the association between religious theology and health care policy attitudes. We find that controlling for religious faith, political partisanship, and social-demographic characteristics, religious theology more strongly associates with White health care policy attitudes than it is for Blacks and Hispanics. Whereas theologically liberal Whites are more likely than their conservative counterparts to support universal healthcare and/ or Obamacare, we observed no such relationship among Blacks and Hispanics. This is true of both the general population and clergy.
\end{abstract}

\section{INTRODUCTION}

On March 23, 2010, President Barack Obama signed his signature legislation, The Patient Protection and Affordable Care Act (ACA; Obamacare). This act aimed to increase the number of Americans with health insurance. Some of the ways it sought to do so include; expanding the number of Americans eligible for Medicare and Medicaid, allowing parents to cover their children on their health insurance up to age 26, requiring all Americans to purchase health insurance or pay a fine, and establishing private insurance marketplaces in all states to sell subsidized insurance to individuals and small groups. While supporters and opponents alike have criticized the health coverage mandate and marketplace costs, by many accounts the ACA is accomplishing its goal. As of 2016, the national 
uninsured rate was down to $8.6 \%$, a historic low, and 20 million individuals had gained healthcare as a result of the ACA (Avery, Finegold, and Whitman 2016). In addition, there is evidence indicating that the ACA reduced government health care spending by 2.3 trillion dollars (Emanuel 2019).

Religious groups are among the strongest supporters of the ACA and universal government provided health insurance more generally. The political consciousness of many religious activists that support public policies aimed at insuring more Americans is heavily informed by a belief that God calls followers to aid the poor, the sick, and the powerless (Green, Jones, and Cox 2009). Faithful Reform in Health, a coalition of more than 30 organizations representing Mainline and Evangelical Protestants, Catholics, Muslims, Buddhists, and Jews, is one such group of religious activists. In August 2009, they launched "40 Days for Health Reform", analogous to Jesus's retreat to the Judean desert for 40 days to more clearly listen and contemplate God's mission for him, to promote proposed health care legislation (Gehring 2009). Clergy members led 50 prayer vigils and meetings in 18 states with members of Congress. The campaign bought cable television and radio ads that reportedly generated thousands of emails, phone calls, and letters to Congress (Rosen and Clement 2009). In February 2012, this organization submitted its "Brief Of Amici Curiae Submitted On Behalf Of Faithful Reform In Health Care and the Wisc. Health Care Working Group In Support Of Respondent's Position On Medicaid" that called on the Supreme Court to not rule the ACA's Medicaid expansion as unconstitutional as called for in the National Federation of Independent Business versus Sebelius, 567 U.S. 519 (2012).

Amidst concerns that the Republican-controlled 115th U.S. Congress and Republican President Donald Trump would repeal the ACA, religious leaders from the Evangelical Lutheran Church in America, the Franciscan Network, the National Council of Churches, the Society of St. Vincent de Paul, the United Church of Christ, and several other religious organizations wrote a joint letter to Congress discouraging them from repealing the act. In their letter, they stated: "Our concerns are neither political nor ideological. Faith communities are committed to a faith-inspired moral vision of healthcare that offers health, wholeness, and human dignity for all" (Society of St. Vincent de Paul 2017). Similarly, the National Council of Churches, the National Association of Evangelicals, the U.S. Conference of Catholic Bishops, and other faith groups passed numerous resolutions before and after the passage of the ACA in 2010 calling for policies aimed at providing more affordable and accessible health care coverage, particularly for the poor. 
It bears saying that religious groups that support government-sponsored health care coverage for the poor and uninsured do not speak for all religious groups or even the clergy and congregants that affiliate with their religious denominations and faiths. We maintain that one's theological orientation likely informs individual perspectives about the government's role in providing services to citizens, healthcare specifically. It is quite likely that persons who share the religious belief system of groups like Faithful Reform in Health Care (2019), and believe they are called by God to challenge individuals and institutions that exploit the poor and powerless are more likely than individuals that reject this premise to support policies aimed at providing more affordable health insurance. We also believe that race matters. Blacks and Hispanics are poorer, have worse health outcomes, are more likely to have experienced discrimination or limited access to services, and depend upon government-funded programs and charities for healthcare (Williams and Collins 2016). These racial experiences likely impact the extent to which religious belief systems inform views about the government's responsibility in providing healthcare.

In testing these assumptions, we rely upon three surveys, two of the general population and one of the clergy. Many studies assume theological differences are at play when examining religious faith differences in support for health care policy attitudes (Green, Jones, and Cox 2009; Rosen and Clement 2009; Wilson 2009). Few, however, directly examine the association between identification with liberal/progressive relative to conservative religious ideals with health care policy attitudes. Using multiple surveys allows us to more confidently make claims about how race and religious beliefs associate with health care policy attitudes. Before testing our contentions, we discuss the connection between religious beliefs and political attitudes. We then empirically examine the connection between race and religious identity/beliefs with health care policy attitudes. Finally, we discuss the theoretical and practical implications of our findings.

\section{RELIGIOUS FAITH AND POLITICAL ATTITUDES}

Much of the work on religion and political attitudes shows that Evangelical Protestants are more likely than other faith groups and secular Americans to identify as politically conservative, Republican, and to vote for Republican candidates (Clement and Green 2011; Smidt 
2013; Brown and Brown 2015). It follows that Evangelicals are more likely than others to oppose government programs aimed at reducing poverty, racial inequality, and raising taxes on rich individuals and corporations (Green, Jones, and Cox 2009; Wilson 2009; McCarthy et al. 2016). Evangelicals are also less likely than others to support Obamacare (Rosen and Clement 2009) and, more generally, to believe that the federal government should guarantee health insurance for all citizens, even if it means raising taxes on individuals and businesses (Jones, Cox, \& NavarroRivera, 2013).

\section{RELIGIOUS IDEOLOGY ON THE RIGHT}

Theological differences along religious affiliation lines may help explain the different positions Evangelical Protestants and others take on the government's role in investing in individuals and communities and providing a safety net for those that fall upon hard times. By this, we mean that Evangelicals are more likely than others to claim membership in religiously conservative political organizations like the National Right to Life Committee, a pro-life lobbying firm and think-tank located in WA, DC (Green, Jones, and Cox 2009). They are also more likely than others to identify as religiously conservative and, whether or not they are actual members or religiously conservative organizations, with the religious right (Jones et al. 2013).

Religious conservatives tend to believe that societal problems result from sinful individual behaviors. Societal redemption, therefore, is only possible when individuals commit themselves to Jesus Christ (Emerson and Smith 2001; McDaniel 2016). Because salvation is viewed as an individual responsibility, members of the religious right emphasize individual accountability in all aspects of life, including healthcare (McDaniel 2016; Franz 2018). Therefore, those who identify with the religious right tend to view social problems as consequences of moral decay and attribute their causes to individual failure rather than societal dysfunction (Emerson and Smith 2001; McDaniel 2016). This strong emphasis on individualism and personal accountability is fundamentally incompatible with political or social interventions that address systemic or structural forces (Emerson and Smith 2001; Franz 2018).

It follows that religious conservatives would be more likely than their liberal counterparts to believe that if enough people were brought to Christ, social ills would take care of themselves (Green, Jones, and Cox 
2009; Jones et al. 2013) and that the main cause of America's problems is moral decay (Green, Jones, and Cox 2009). Religious conservatives also tend to adhere to a civil religious outlook that suggests that the U.S. free market and government, which has produced the strongest nation on the planet, is indicative of their exceptional status in God's purview. For example, religious conservatives are more likely than religious liberals to believe that "God has granted America a special role in human history" (Jones et al. 2013). From this perspective, the extent to which social inequality exists in the United States is not a consequence of systemic oppression, but a lack of effort (Emerson and Smith 2001). Individuals who have a stronger belief that Americans possess unique opportunities also tend to believe that the extent to which social inequalities, such as disparities in health care access, persist is less a consequence of blocked opportunities than a weak work ethic (Jackson et al. 2004). To that end, religious conservatives may see health disparities as personal inadequacies rather than as a product of oppression and discrimination that requires government intervention (Emerson and Smith, 2001; Phelan, Link, and Tehranifar 2010).

\section{RELIGIOUS IDEOLOGY ON THE LEFT}

Conversely, Mainline Protestants, Catholics, and Black Protestants are more likely than Evangelical Protestants to believe that social justice is consistent with their faith (Green, Jones, and Cox 2009). Mainline Protestants and Catholics are also more likely than Evangelicals to claim membership in religiously liberal political organizations like Faithful Reform in Health Care (2019). Religious liberals tend to adhere to tenants of the social gospel (Green, Jones, and Cox 2009). The social gospel was developed during the Progressive era of the early 1900s in which theologians such as Walter Rauschenbusch (1918) argued that while industrial capitalism contributed to increasing technological innovation in the country, it also relied upon crushingly low wages, minimal public services, and weak unions that left workers living in squalid conditions that led to disease and immoral behavior. Rauschenbush (1918) further argued that Christians have an obligation to combat sin wherever it exists, be it in individuals or within economic, political and/or legal institutions that contribute to poor qualities of life within industrial cities like Chicago. Social Worker Jane Addams's Settlement House Movement in Chicago was, in part, motivated by a social gospel theological orientation (Morgan 1969; Bowman 
2007). Addam's Hull House Movement provided housing, job skills training, and hygiene training for immigrant workers and their families. Similar to the faith-based health advocacy organizations of today, her movement also lobbied Chicago's city hall to increase funding for housing, sanitation, and public health services for poor immigrant workers living in unsanitary slums. Similarly, Martin Luther King's beloved community theology, civil rights activism, and the Poor People's Campaign aimed at improving the quality of life of the poor was also inspired by Rauschenbusch's social gospel theology. This comes through in his statement about healthcare in America at the second convention of the Medical Committee for Human Rights in Chicago on March 25, 1966, when he stated, "Of all the forms of inequality, injustice in healthcare is the most shocking and inhumane" (Moore 2013).

Like the religious right, the religious left believes that the United States is exceptional. They part with the right, however, in their belief that the nation's covenant with God obliges it to do God's will via being in solidarity with the poor, the marginalized, and powerless as was Jesus (Boff and Boff 1987; Gutierrez 1988; Cone 2010). To make democracy meaningful, religious persons are obliged to aid the poor and improve the quality of life for all God's children, so that they can participate in and contribute to the economy and the betterment of the world. In this sense, religious persons are obliged to challenge structures, even one's own government, that thrive upon the exploitation of the weak (Boff and Boff 1987; Gutierrez 1988; Cone 2010). This ethic reflects an adherence to a liberation theological outlook that suggests religious persons see God in the poor, marginalized, and powerless (Boff and Boff 1987; Gutierrez 1988; Cone 2010). In this sense, Christians are not only to empathize with the poor, but to be in solidarity with them as with their Savior (Boff and Boff 1987; Gutierrez 1988; Cone 2010).

It follows that individuals who identify with the religious left tend to be "communitarian" in nature, meaning they consider community needs as a whole rather than seeing the world from an individualist perspective (Rauschenbush 1918; Curtis 2001; McDaniel 2016; Ledet 2017). Indeed, "the overwhelming majority (87\%) of progressive Christian activists believe that they have a special obligation to solve social problems because of Christ's commandments" (Green, Jones, and Cox 2009). Along these lines, religious liberals are considerably more likely than conservatives to believe that, "In the Bible, when Jesus and prophets talked about taking care of the poor, they were primarily talking about their obligation to create a just society" (Jones et al. 2013). 


\section{RELIGIOUS BELIEFS AND IDENTITY AND POLITICAL ATTITUDES}

Given these theological differences, it is plausible that individuals who identify as the religious left or religious liberals are more likely than their conservative counterparts on the right to believe that promoting equality and fairness and providing a public safety net for people who are facing hardships are important moral guides for government policy. Conversely, religious conservatives are more likely to believe that encouraging people to live more responsible lives is an important moral guide for government policy (Jones et al. 2013). The religious left is also less likely than the right to oppose redistributive policies which include programs and services addressing poverty, welfare, wages, taxes, and social services including healthcare and social insurance (Scheve and Stasavage 2006; Bean, Gonzalez, and Kaufman 2008; McCarthy, et al. 2016). It follows that members of religious left political organizations are more concerned about healthcare and more likely to support comprehensive health insurance for all Americans than are religious right political activists (Green, Jones, and Cox, 2009).

\section{RACE, RELIGION, AND POLITICAL ATTITUDES}

There is reason to believe that race may impact the association between theology and health care attitudes. As stated earlier, Blacks and Hispanics are much more likely to rely upon government agencies and non-profit organizations for healthcare than are Whites. Blacks are also more likely than Whites to suffer from health complications, and both groups are more likely than Whites to have shorter life spans (Williams and Collins 2016). To that end, it is plausible that African Americans and Hispanics, regardless of theological orientation, are quite aware of the need for expanded health care coverage to insure themselves, their families, friends, and groups more generally. So, although Blacks are more likely than Whites to trust the information they receive about Obamacare at their places of worship (Kaiser 2016), it is quite likely that, regardless of theological orientation, Blacks and Hispanics are more likely to support government efforts to increase health care coverage to the general population. In contrast, relative to Blacks and Hispanics, White's greater access to private health insurance and better health outcomes may contribute to a greater diversity of opinion about the degree 
to which the government should provide healthcare for those in need. The greater variability in opinion on this matter may allow for a greater chance that White's religious theological outlook associates with their health care attitudes.

This is partially borne out in other studies. In looking at Black clergy within historically Black Protestant denominations McDaniel (2003) found that the more theologically conservative Church of God in Christ and liberal African Methodist Episcopal clergy were equally likely to support universal government-provided healthcare. Similarly, Franz and Brown (2020) find that among Whites, individuals that attended worship services more often and affiliated with Evangelical Protestant denominations were more likely than others to oppose Obamacare. In contrast, worship attendance and religious affiliation were unrelated to how Blacks and Hispanic felt about that policy. It is plausible that the association between religious beliefs and identity with health care policy attitudes is also stronger among Whites than among Blacks and Hispanics. This leads to our primary hypotheses.

\section{HYPOTHESES}

(1) Among Whites, religious liberals are more likely than religious conservatives to support Obamacare/ACA and universal governmentprovided healthcare.

(2) Among Blacks and Hispanics, religious beliefs and identity are unrelated to health care policy attitudes.

\section{SAMPLE}

We rely on three surveys to test our hypotheses. ${ }^{1}$ These surveys were collected in different years, with different modes and sampling frames (See Appendix A) and rely upon different units of analyses.

(1) 2000/2009 The Cooperative Clergy Project

(2) 2012 American National Election Study (ANES)

(3) Public Religion Research Institute (PRRI)/ Brookings 2013 Economic Values Survey

While the PRRI and the ANES are general population studies, the Cooperative Clergy Project is a study of the clergy. As indicated in the Measures section and Appendix A, these surveys do not use identical 
questions to assess religious beliefs and identity and health care policy attitudes. The degree to which we find that attending political congregations associates with White, Black and/or Hispanic health care policy attitudes should, therefore, provide fairly strong support for our hypotheses.

\section{MEASURES}

\section{Health Care Policy}

We assess health care policy attitudes by examining the extent to which respondents support Obamacare, supported President Obama's work on healthcare, oppose cuts to health care spending, and support universal healthcare, government-sponsored healthcare for all Americans (See Appendix B for greater detail).

\section{Religious Beliefs and Identity}

To assess religious identity, we rely upon measures reported in Appendix C that assess respondent identification with the religious left or progressive social movements, with the religious right or conservatives, or something else. Our religious belief measures assess the extent to which respondents adhere to tenants of liberation theology, the social gospel, and conservative religious beliefs.

\section{Control Variables}

We control for religious affiliation ${ }^{2}$, political partisanship, and the following social demographic characteristics; age, gender, education, region, and income.

\section{STATISTICAL ANALYSES}

We report predicted probability estimates based upon logit regression analyses to examine the association between religious beliefs and identity with health care policy attitudes while controlling for political party, religious faith, and social-demographic characteristics. ${ }^{3}$ 


\section{RESULTS}

\section{ANES, 2012}

The analyses based upon the 2012 ANES data presented in Table 1 indicate that Whites who identify as religious liberals are more likely than Whites who identify as religious conservatives or as something else to support Obamacare and the job President Obama did on healthcare and to oppose cuts in health care spending. Like Whites, religiously liberal Hispanics were more likely than Hispanics that maintained some other religious identity, including none at all, to support Obamacare. In all other instances, however, religious identity was unrelated to Black and Hispanic health care policy attitudes.

This study also suggests that religious beliefs and identity play a statistically stronger role in associating with White health care policy attitudes than it does for Blacks and Hispanics. Our interaction analyses suggest the following: (1) relative to religious conservatives, being religiously liberal more strongly associates with White opposition to health care spending than it does for Blacks; and (2) being religiously liberal more strongly associates with White support for the job Obama did on healthcare than it does for Blacks or Hispanics.

\section{PRRI, 2013}

As in the ANES analyses, the analyses based upon the 2013 PRRI reported in Table 2 indicate that religious identification and beliefs more consistently associate with White health care policy attitudes than for Blacks and Hispanics. Whites who identify with the religious left are more likely to support Obamacare and universal healthcare than Whites who identify with the religious right or as something else. Whites that adhere to the social gospel are more likely than other Whites to support Obamacare and universal healthcare; on the other hand, Whites that adhere to conservative religious societal beliefs are less likely to do so. Like Whites, Blacks who identify with the religious left are more likely than Blacks who identify as something else to support Obamacare. The remaining religious identification and belief measures, however, are unrelated to Black and Hispanic health care policy attitudes.

This study also suggests that religious beliefs and identity play a statistically stronger role in predicting White health care policy attitudes than it does for Blacks and Hispanics. Our interaction analyses suggest: (1) being 
Table 1. Probability estimates of health care policy attitudes by race and religious identity: controls for religious faith, worship attendance, partisanship, social demographic characteristics, and mode ${ }^{5}$

\begin{tabular}{|c|c|c|c|}
\hline & Support Obamacare & $\begin{array}{l}\text { Oppose cutting health } \\
\text { care spending }\end{array}$ & $\begin{array}{l}\text { Approve of the way President } \\
\text { Obama is handling healthcare }\end{array}$ \\
\hline \multicolumn{4}{|l|}{ Whites } \\
\hline Religious progressives & $0.3784[0.3150,0.4418]$ & $0.8366[0.7924,0.8807]$ & $0.4565[0.3850,0.5281]$ \\
\hline Religious conservatives & $0.2566[0.2141,0.2991]^{* *}$ & $0.6970[0.6558,0.7382]^{* *}$ & $0.2643[0.2178,0.3108]^{* *}$ \\
\hline Religiously something else & $0.2976[0.2758,0.3194]^{*}$ & $0.7629[0.7440,0.7819]^{* *}$ & $0.3476[0.3225,0.3727]$ \\
\hline$N=$ & 3,509 & 3,275 & 3,509 \\
\hline \multicolumn{4}{|l|}{ Blacks } \\
\hline Religious progressives & $0.7825[0.6952,0.8698]$ & $0.8437[0.7667,0.9207] \mathrm{a}$ & $0.9212[0.8674,0.9750] \mathrm{a}$ \\
\hline Religious conservatives & $0.7102[0.6570,0.7634]$ & $0.8521[0.8113,0.8929] \mathrm{a}$ & $0.9129[0.8794,0.9463] \mathrm{a}$ \\
\hline Religiously something else & $0.7402[0.7015,0.7789]$ & $0.8572[0.8265,0.8879]$ & $0.9564[0.9391,0.9737] \mathrm{a}$ \\
\hline$N=$ & 1,021 & 959 & 1,021 \\
\hline \multicolumn{4}{|l|}{ Hispanics } \\
\hline Religious progressives & $0.5909[0.4824,0.6993]$ & $0.8600[0.7831,0.9370]$ & $0.7062[0.6010,0.8114] \mathrm{a}$ \\
\hline Religious conservatives & $0.4851[0.4091,0.5611]$ & $0.7917[0.7270,0.8563]$ & $0.6594[0.5820,0.7369] \mathrm{a}$ \\
\hline Religiously something else & $0.4476[0.4070,0.4882]^{*}$ & $0.8595[0.8302,0.8888]$ & $0.6525[0.6099,0.6951]$ \\
\hline$N=$ & 1,009 & 923 & 1,009 \\
\hline
\end{tabular}

Source: ANES 2012

$*<0.05 ; * *<0.01$; confidence intervals are in parentheses ${ }^{6}$.

$\mathrm{a}=$ interactive effect is significant: Black or Hispanic effect is significantly different from the White effect. 
Table 2. Probability estimates of health care policy attitudes by race and religious identity and beliefs: Controls for religious faith, worship attendance, partisanship, social demographic characteristics, and mode ${ }^{7}$

\begin{tabular}{|c|c|c|}
\hline & Support Obamacare & Support universal health care \\
\hline \multicolumn{3}{|l|}{ Whites } \\
\hline Religious left ${ }^{8}$ & $0.5492[0.4692,0.6291]$ & $0.6153[0.4980,0.7325]$ \\
\hline Religious right & $0.2891[0.2265,0.3518]^{* *}$ & $0.2195[0.1230,0.3159]^{* *}$ \\
\hline Religiously something else & $0.3848[0.3522,0.4174]^{* *}$ & $0.4323[0.3806,0.4839]$ \\
\hline Conservative Religious societal belief & $0.3502[0.3126,0.3878]$ & $0.3326[0.2755,0.3897]$ \\
\hline Does not adhere to conservative Religious societal belief & $0.4267[0.3820,0.4713]^{*}$ & $0.5209[0.4489,0.5929]^{* *}$ \\
\hline Adhere to social gospel & $0.4460[0.4001,0.4920]$ & $0.5260[0.4510,0.6011]$ \\
\hline Does not adhere to social gospel & $0.3512[0.3190,0.3834]^{* *}$ & $0.3540[0.3031,0.4048]^{* *}$ \\
\hline$N=$ & 1,443 & 743 \\
\hline \multicolumn{3}{|l|}{ Blacks } \\
\hline Religious left & $0.6591[0.5269,0.7912]$ & $0.6280[0.4178,0.8383] \mathrm{a}$ \\
\hline Religious right & $0.4759[0.3025,0.6493]$ & $0.8544[0.6928,1.0160] \mathrm{a}$ \\
\hline Religiously something else & $0.4269[0.3148,0.5390]^{*}$ & $0.7934[0.6452,0.9416] \mathrm{a}$ \\
\hline Conservative Religious societal belief & $0.4813[0.3883,0.5742]$ & $0.7301[0.6027,0.8574]$ \\
\hline Does not adhere to conservative Religious societal belief & $0.5736[0.4175,0.7297]$ & $0.8336[0.6463,1.0210]$ \\
\hline Adhere to social gospel & $0.4920[0.3864,0.5977]$ & $0.6551[0.4743,0.8359]$ \\
\hline Does not adhere to social gospel & $0.5252[0.4137,0.6367]$ & $0.8432[0.7218,0.9645]$ \\
\hline$N=$ & 194 & 93 \\
\hline \multicolumn{3}{|l|}{ Hispanics } \\
\hline Religious left & $0.4428[0.2969,0.5887] \mathrm{a}$ & $0.7086[0.4997,0.9175] \mathrm{a}$ \\
\hline Religious right & $0.3813[0.2033,0.5593] \mathrm{a}$ & $0.7148[0.4606,0.9690] \mathrm{a}$ \\
\hline Religiously something else & $0.5189[0.4301,0.6076] \mathrm{a}$ & $0.8474[0.7577,0.9371] \mathrm{a}$ \\
\hline Conservative religious societal belief & $0.4702[0.3811,0.5593]$ & $0.8455[0.7478,0.9433] \mathrm{a}$ \\
\hline Does not adhere to conservative Religious societal belief & $0.4954[0.3849,0.6060]$ & $0.7469[0.6102,0.8835] \mathrm{a}$ \\
\hline Adhere to social gospel & $0.5134[0.4179,0.6090]$ & $0.7944[0.6785,0.9104]$ \\
\hline Does not adhere to social gospel & $0.4456[0.3478,0.5434]$ & $0.8204[0.7130,0.9277]$ \\
\hline$N=$ & 231 & 118 \\
\hline
\end{tabular}

Source: PRRI, 2013

$*<0.05 ; * *<0.01$; confidence intervals are in parentheses.

$\mathrm{a}=$ interactive effect is significant: Black or Hispanic effect is significantly different from the White effect. 
a member of the religious left, believing in the social gospel, and rejecting conservative religious beliefs more strongly associates with support for universal healthcare among Whites than Hispanics. (2) Being a member of the religious right more strongly associates with support for universal healthcare among Whites than among Blacks or Hispanics.

\section{The Cooperative Clergy Project}

The same pattern of relationships that we observed among the general population can be observed among the clergy. Data from the Cooperative Clergy Project, presented in Table 3, suggest that holding progressive religious beliefs more consistently associates with the health care policy attitudes of White clergy than it does for Black and Hispanic clergy. White clergy who agree with liberation theology and the centrality of social justice to the gospel is more likely than another White clergy to support government-sponsored universal healthcare. However, these religious beliefs are unrelated to Black and Hispanic clergy's assessment of health care policy. The interaction analyses indicate that religious beliefs play a statistically stronger role in associating with White clergy support for universal health care policy than for Black clergy.

\section{Summary}

In short, our analyses, based upon three separate studies, suggest that when accounting for political party, religious affiliation, and social-demographic characteristics, identifying with religious-based social movements and religious beliefs and identity more consistently associates with White health care policy attitudes than with Blacks and Hispanics in general and clergy specifically. ${ }^{4}$

\section{DISCUSSION}

Using two national general population and one clergy survey, we examined racial differences in the association between religious beliefs and identity and health care policy attitudes. We find that when controlling for religious affiliation, political partisanship, and social-demographic characteristics, religious beliefs and identity more strongly associate with White health care policy attitudes than for Blacks and Hispanics. Whereas religiously liberal/progressive Whites are more likely than their 
Table 3. Probability Estimates of Clergy Support for Government-funded Universal HealthCare by Race and Religious Beliefs: Controls for religious faith, worship attendance, partisanship, social demographic characteristics, and mode. ${ }^{9}$

\begin{tabular}{llcc}
\hline & White & Blacks & Hispanic \\
\hline Does not adhere to liberation & $0.3631[0.3506$, & $0.8063[0.7517$, & $0.6750[0.5704$, \\
theology and social justice & $0.3756]^{* *}$ & $0.8610] \mathrm{a}$ & $0.7795]$ \\
gospel & & & \\
Adhere to liberation theology and & $0.6279[0.6045$, & $0.8875[0.8304$, & $0.8395[0.6856$, \\
social justice gospel & $0.6513]$ & $0.9445] \mathrm{a}$ & $0.9934]$ \\
$N=$ & 10,654 & 362 & 124 \\
\hline
\end{tabular}

Source: 2000 \& 2009 Cooperative Clergy Project.

$*<0.05 ; * *<0.01$; confidence intervals are in parentheses.

$\mathrm{a}=$ interactive effect is significant: Black or Hispanic effect is significantly different from the White effect.

conservative counterparts to support universal healthcare and/or Obamacare, we have less evidence that this relationship holds true for Blacks and Hispanics. This is the case for both the general population and clergy, suggesting that one's religious worldview plays a similar role in informing clergy health care attitudes as it does for clergy.

Why may this be the case? On this point, we can only theorize. We feel it plausible that the disparate racial experiences of Whites relative to Blacks and Hispanics may help explain why religious beliefs and identity matters to White health care policy attitudes, but not to Blacks and Hispanics. Blacks and Hispanics are more likely than Whites to live further away from high ranking hospitals and receive healthcare through government-sponsored programs like Medicaid that provide lower reimbursement rates for hospitals and service options for clients than private health care plans (Williams and Collins 1995; 2016). Along these lines, these groups are more likely than Whites to receive healthcare through community health centers that provide more limited services than do hospitals (Williams and Collins 1995; 2016). It follows that Blacks and Hispanics are less satisfied with their healthcare than are Whites (Gallup, n.d.). Blacks and Hispanics are also more likely than Whites to report being unable to pay monthly health insurance premiums and the deductible and to be concerned about unexpected medical bills (Kaiser 2018). These experiences may lend itself to Blacks and Hispanics, regardless of their theological orientation, desiring more affordable and comprehensive coverage, as enumerated in ACA and even more so with universal government-sponsored healthcare. To the point, for a disproportionate amount of Blacks and Hispanics, universal healthcare may be much less 
a philosophical/theological quandary than a practical necessity. This is not at all to suggest that religious beliefs and identity are unimportant to Black and Hispanic health care policy attitudes or activism. Both Blacks and Hispanics are more likely to attend congregations that identify as social justice-oriented and that affiliate with local faith-based community organizing firms, like MOSES in Detroit, MI or PICO in Oakland, CA that have long called for more affordable health care insurance (Wood and Warren, 2002 2002). It is to say, however, that Blacks and Hispanics who maintain liberal/progressive theological orientations, as do the clergy and lay persons active in groups like MOSES and PICO, are no more or less supportive of universal healthcare than their more theologically conservative counterparts.

While the government's role in providing healthcare is a practical question for many Whites, unlike for Blacks and Hispanics, it is also a theological issue. Consistent with the social gospel tradition, White religious liberals may see supporting government reform that extends providing healthcare to a wider breadth of the citizenry, particularly the poor, as consonant with their doing God's will in reducing human suffering. Adherents to a liberation theological tradition may feel called to be in solidarity with the poor and the powerless, and therefore see it as their religious and civic mission to support policies that affirm and strengthen them and allow them to become productive members of society, even if they themselves do not directly benefit and may be materially harmed. This is a very different outlook than religious conservatives who see the nation as blessed by God's provenance. In the same way that individuals are tasked with finding salvation for themselves, they are also tasked with availing themselves of opportunities. We see this dichotomy quite clearly among religious activists affiliated with liberal organizations like Faithful Reform in Health Care (2019) who are much more concerned about healthcare and the uninsured than are religious activists affiliated with conservative religious organizations. In our study, when accounting for religious affiliation, political partisanship, and social-demographic characteristics, we see this same dichotomy among religiously liberal and conservative White individuals and clergy.

In terms of why this dichotomy exists, we speculate that there could be a number of factors that may impact the health care views of religious conservatives. First, because many have an individualist orientation, they are likely to view the lack of access to adequate healthcare as a personal shortcoming, rather than a structural, societal problem. Religious conservatives believe that individuals should be accountable to themselves and may 
view the ACA as something that undermines self-reliance and independence. While conservatives are not opposed to helping others, they do not believe it is the government's role to intervene. Current messages from the GOP (Grand Old Party) reinforce this perspective by emphasizing individual choice, a free market, and less government oversight. Stories about the horrors of socialized medicine and the creation of "death panels" are also narratives used to incite fear and encourage rejection of government health care programs which reinforce existing beliefs among conservatives. Also, many religiously conservative people oppose coverage for birth control and abortifacients like the morning after pill because they believe it supports fornication between unmarried people and promotes abortion. Both of these are covered and protected under the ACA. In summary, beliefs based on conservative religious teachings are ultimately what drive conservatives away from supporting government-supported healthcare. From this perspective, it is considered immoral and contrary to what God wants.

Despite the consistency of our findings, we recognize our inability to go beyond speculating as to why racial differences persist in the association between religious beliefs and identity and health care policy attitudes. In-depth ethnographic studies that examine how people theologically understand healthcare would go a long way in helping us understand the connection between religious beliefs and identity and health care attitudes among racially diverse groups of Americans. Nonetheless, we believe our study provides an important starting point for understanding how religion informs American health care policy attitudes.

\section{NOTES}

1. See Appendix A for detailed information on each sample.

2. We measure religious affiliation in two ways. If the survey asks Protestant respondents the denomination with which they identify, we employ Steensland et al.'s (2000) denominational classification method to determine Evangelical Protestants, Mainline Protestants, and Historically Black Protestants. If the survey does not ask respondents if they identity with a specific Protestant denomination but ask if they are born-again Christians, we operationalize Evangelical Protestants as individuals that identify as Protestant and born-again Christians. Mainline Protestants are Protestants who do not identify as born-again Christians. In both classification schemes, Catholics, secular persons, and non-Christians were based upon self-report.

3. The probability estimates listed in Tables 1-3 are derived from logit regression analyses of worship-goers that assess the relationship between religious belief or identity and health care policy attitudes while controlling religious faith, political partisanship, and social-demographic variables. That being said, the estimates for Table 1 is based upon the following formula; $\operatorname{Pr}(\mathrm{y}=1 \mid \bar{X}, \max \mathrm{xk})$ - $\operatorname{Pr}(\mathrm{y}=1 \mathrm{I} \overline{\mathrm{X}}, \mathrm{min} \mathrm{xk})$, in which $\mathrm{Y}$ represents health care policy attitudes and $\mathrm{X}$ represents religious belief or identity.

4. All of our logit regression analyses, upon which our predicted probability analyses are based, are available upon request. 
5. The highlighted figures indicate that there is significant difference between the Black and/or Hispanic effect sizes relative to that of Whites.

6. Religious Conservatives and Religiously Something Else are compared to Religious Progressives.

7. The highlighted figures indicate that there is significant difference between the Black and/or Hispanic effect sizes relative to that of Whites.

8. The Religious Right and Religiously Something Else are compared to the Religious Left.

9. The highlighted figures indicate that there is significant difference between the Black and/or Hispanic effect sizes relative to that of Whites.

\section{REFERENCES}

Avery, Kelsey, Kenneth Finegold, and Amelia Whitman. 2016. Affordable Care Act Has Led to Historic, Widespread Increase in Health Insurance Coverage. Department of Health and Human Services. ASPE Brief. Retrieved from: https://aspe.hhs.gov/ system/files/pdf/207951/ChartpackACAHistoricIncreaseCoverage.pdf.

Bean, Lydia, Marco Gonzalez, and Jason Kaufman. 2008. "Why Doesn't Canada Have an American-Style Christian Right? A Comparative Framework for Analyzing the Political Effects of Evangelical Subcultural Identity." Canadian Journal of Sociology 33 (4): 899-943.

Boff, Leonardo, and Cleodovis Boff. 1987. Introducing Liberation Theology. Maryknoll, NY: Orbis Books.

Bowman, Matthew. 2007. "Sin, Spirituality, and Primitivism: The Theologies of the American Social Gospel, 1885-1917." Religion and American Culture 17 (1): 95-126.

Brown, R. Khari, and Ronald E. Brown. 2015. "Race/Ethnicity, Religion and Partisan Leanings." Review of Religious Research 57 (4): 469-505.

Clement, Scott, and John C. Green. 2011. "The tea Party, Religion and Social Issues." Pew Forum on Religion and Public Life 23. Accessed on Jan. 15, 2020 from,

Cone, James H. 2010. A Black Theology of Liberation. Maryknoll, NY: Orbis Books.

Curtis, Susan. 2001. A Consuming Faith: The Social Gospel and Modern American Culture. Columbia, MO: University of Missouri Press.

Emanuel, Ezekiel J. 2019. Name the Much-Criticized Federal Program That Has Saved the U.S. \$2.3 Trillion. Hint: It Starts with Affordable. STAT. March. Retrieved from: https://www.statnews.com/2019/03/22/affordable-care-act-controls-costs/

Emerson, Michael O., and Christian Smith. 2001. Divided by Faith: Evangelical Religion and the Problem of Race in America. Oxford, England: Oxford University Press.

Faithful Reform in Health Care. 2019. Accessed on August 8, 2019 from: http:// faithfulreform.org/

Franz, Berkley. 2018. "Encouraging Accountability: Evangelicals and American Health Care Reform." Critical Research on Religion 6 (2): 184-204.

Franz, Berkeley, and R. Khari Brown. 2020. Race, Religion and Support for the Affordable Care Act. Review of Religious Research. 62 (1): 101-120.

Gallup. n.d. Race Relations. The Gallup Poll. Accessed on Nov. 25, 2019 from: https:// news.gallup.com/poll/1687/race-relations.aspx

Gehring, John. 2009. 40 Days for Health Reform. Sojourners, August 27. Accessed on August 9, 2019 from: https://sojo.net/articles/40-days-health-reform

Green, John C., Robert P. Jones, and Daniel Cox. 2009. Faithful, Engaged, and Divergent: A Comparative Portrait of Conservative and Progressive Religious Activists in the 2008 Election and Beyond. Ray C. Bliss Institute of Applied Politics and Public Religion Research. University of Akron and Public Religion Research. Accessed on Nov. 152019 from, https://www.uakron.edu/bliss/research/archives/2008/ReligiousActivistReport-Final. pdf 
Gutierrez, Gustavoet al.. 1988. A Theology of Liberation: History, Politics, and Salvation. Maryknoll, NY: Orbis Books.

Jackson, James S. (James Sidney), Vincent L. Hutchings, Ronald Brown, and Cara Wong. 2004. National Politics Study, 2004. Ann Arbor, MI: Inter-university Consortium for Political and Social Research [distributor], 2009-03-23. https://doi.org/10.3886/ICPSR24483.v1

Jones, Robert P., Daniel Cox, E.J. Dionne, Jr., William A. Galston, and Juhem NavarroRivera. 2013. "Do Americans Believe Capitalism \& Government Are Working? Religious Left, Religious Right \& the Future of the Economic Debate." PRRI. Accessed on Jan. 5, 2020 from, http://www.prri.org/research/economic-values-survey-07-2013/.

Jones, Robert P., Daniel Cox, and Juhem Navarro-Rivera. 2013. THE 2013 AMERICAN VALUES SURVEY: In Search of Libertarians in America. Public Religion Research Institute (2013) October 29. Accessed on August 8, 2019 from: https://www.prri.org/ wp-content/uploads/2013/10/2013.AVS_WEB-1.pdf.

Kaiser, Henry J. 2016. Family Foundation. Kaiser Family Foundation Poll: October 2016 Kaiser Health Tracking Poll, Oct, 2016 [dataset]. USKFF2016-1018, Version 2. Princeton Survey Research Associates International [producer]. Cornell University, Ithaca, NY: Roper Center for Public Opinion Research, RoperExpress [distributor], accessed Aug-10-2019.

Kaiser, Henry J. 2018. Family Foundation. Kaiser Family Foundation Poll: Late Summer 2018 Kaiser Health Tracking Poll: The Election, Pre-Existing Conditions, and Surprises on Medical Bills, Aug, 2018 [dataset]. 31115453, Version 2. Social Science Research Solutions (SSRS) [producer]. Cornell University, Ithaca, NY: Roper Center for Public Opinion Research, RoperExpress [distributor], accessed Aug-5-2019.

Ledet, Richard. 2017. "Sorting the Left From the Rest: The Communitarian Religious Perspective and Liberal Economic Attitudes.” Politics \& Policy 45 (6):1051-1079.

McCarthy, Angela F., Nicholas T. Davis, James C. Garand, and Laura R. Olson. 2016. "Religion and Attitudes Toward Redistributive Policies among Americans." Political Research Quarterly 69 (1):121-133.

McDaniel, Eric. 2003. "Black Clergy in the 2000 Elections." Journal for the Scientific Study of Religion 42(4):533-546.

McDaniel, Eric L. 2016. "What Kind of Christian Are You? Religious Ideologies and Political Attitudes." Journal for the Scientific Study of Religion 55:288-307.

Moore, Amanda. 2013. Tracking Down Martin Luther King, Jr.'s Words on Health Care. The Huffington Post. March 20. Accessed on August 8, 2019 from: https://www. huffpost.com/entry/martin-luther-king-health-care_b_2506393.

Morgan, J. Graham. 1969. "The Development of Sociology and the Social Gospel in America." Sociological Analysis 30(1):42-53.

Phelan, Jo C., Bruce G. Link, and Parisa Tehranifar. 2010. "Social Conditions as Fundamental Causes of Health Inequalities: Theory, Evidence, and Policy Implications." Journal of Health and Social Behavior 51 (1):S28-S40.

Rauschenbush, Walter. 1918. A Theology for the Social Gospel. New York: Macmillan.

Rosen, Anne Farris, and Scott Clement. 2009. Religious Groups Weigh In on Health Care Reform. Pew Research Center's Forum on Religion \& Public Life. October 8. Accessed on August 8, 2019 from: https://www.pewforum.org/2009/10/08/religious-groupsweigh-in-on-health-care-reform/.

Scheve, Kenneth, and David Stasavage. 2006. "Religion and Preferences for Social Insurance." Quarterly Journal of Political Science 1: 255-286.

Smidt, Corwin E. 2013. American Evangelicals Today. Lanham: Rowman \& Littlefield Publishers. 
Society of St. Vincent de Paul 2017. Interfaith Coalition Letter to Congress Regarding Proposed Changes to Affordable Care Act. Retrieved from: https://www.svdpusa.org/ Portals/0/WISC\%20Healthcare\%20Statement\%20final.pdf.

Steensland, Brian, Jerry Z. Park, Mark D. Regnerus, Lynn D. Robinson, W. Bradford Wilcox, and Robert D. Woodberry. 2000. "The Measure of American Religion: Toward Improving the State of the Art." Social Forces 79 (1): 291-318.

Williams, David R., and Chiquita Collins. 1995. "US socioeconomic and Racial Differences in Health: Patterns and Explanations." Annual Review of Sociology 21 (1): 349-386.

Williams, David R., and Chiquita Collins. 2016. Racial residential segregation: a fundamental cause of racial disparities in health. Public Health Reports. 116 (5): 404-416

Wilson, J. Mathew. (2009). "Religion and American Public Opinion: Economic Issues." In The Oxford Handbook of Religion and American Politics, edited by Corwin E. Smidt, Lyman A. Kellstedt and James L. Guth, 191-216. Oxford: Oxford University Press.

Wood, Richard L, and Mark R Warren. 2002. "A Different Face of Faith-based Politics: Social Capital and Community Organizing in the Public Arena." International Journal of Sociology and Social Policy 22(11):6-54. 


\section{Appendix A}

\begin{tabular}{|c|c|c|c|c|c|c|}
\hline SamplesTitle & Principal investigator & Date & Universe & Mode & Sample size & $\begin{array}{l}\text { Response } \\
\text { rate }\end{array}$ \\
\hline $\begin{array}{l}\text { 2000/2009 The } \\
\text { Cooperative Clergy } \\
\text { Project }\end{array}$ & Corwin Smidt & $\begin{array}{l}\text { 2000-2001/ } \\
\text { March-September } \\
2009\end{array}$ & $\begin{array}{l}\text { American clergy } \\
\text { of religious } \\
\text { congregations }\end{array}$ & $\begin{array}{l}\text { Telephone } \\
\text { and online } \\
\text { survey }\end{array}$ & $\begin{array}{l}\text { Blacks }=362 \\
\text { Whites }=10,654\end{array}$ & $37 \%$ \\
\hline $\begin{array}{l}2012 \text { American } \\
\text { National Election } \\
\text { Study (ANES) }\end{array}$ & $\begin{array}{l}\text { Vincent Hutchings, } \\
\text { Gary Segura, Simon } \\
\text { Jackman, and Ted } \\
\text { Brader }\end{array}$ & $\begin{array}{r}\text { September 8, 2012- } \\
\text { January 24, } 2013\end{array}$ & American adults & $\begin{array}{l}\text { Face-to-Face } \\
\text { and } \\
\text { Internet }\end{array}$ & $\begin{array}{l}\text { Hispanics }=124 \\
\text { Blacks }=1,021 \\
\text { Whites }=3,509\end{array}$ & Not reported \\
\hline $\begin{array}{l}\text { Public Religion } \\
\text { Research Institute } \\
\text { (PRRI)/ Brookings } \\
\text { 2013 Economic } \\
\text { Values Survey }\end{array}$ & $\begin{array}{l}\text { Robert P. Jones, Daniel } \\
\text { Cox, Juhem Navarro- } \\
\text { Rivera, E.J. Dionne } \\
\text { Jr., and William A. } \\
\text { Galston }\end{array}$ & May30-June16, 2013 & American adults & Telephone & $\begin{array}{l}\text { Hispanics = 1,009 } \\
\text { Blacks = 194 } \\
\text { Whites = 1,443 } \\
\text { Hispanics = 231 }\end{array}$ & Not reported \\
\hline
\end{tabular}




\section{Appendix B}

\begin{tabular}{|c|c|c|c|}
\hline $\begin{array}{l}\text { Religious Belief/Identity } \\
\text { Measures Study }\end{array}$ & Variable name & Question wording & $\begin{array}{l}\text { Variable } \\
\text { measurement }\end{array}$ \\
\hline $\begin{array}{l}\text { 2000/2009 The Cooperative Clergy } \\
\text { Project }\end{array}$ & $\begin{array}{l}\text { Adhere to social } \\
\text { justice theology }\end{array}$ & $\begin{array}{l}\text { Do you agree or disagree with these statements? } \\
\text { - Many of the ideas of 'liberation theology' really get } \\
\text { at the heart of the Gospel? } \\
\text { - Social justice is at the heart of the gospel. }\end{array}$ & $\begin{array}{l}0=\text { Does not agree with } \\
\text { both statements } \\
1=\text { Agree with both } \\
\text { statements }\end{array}$ \\
\hline $\begin{array}{l}2012 \text { American National Election } \\
\text { Study (ANES) }\end{array}$ & $\begin{array}{l}\text { Religious progressive } \\
\text { identity }\end{array}$ & Ordered self-description respondent religious identity & $\begin{array}{l}0=\text { Does not identify as } \\
\text { religious progressive } \\
1=\text { Identify as religious } \\
\text { progressive }\end{array}$ \\
\hline $\begin{array}{l}\text { Public Religion Research Institute } \\
\text { (PRRI)/ Brookings } 2013 \\
\text { Economic Values Survey }\end{array}$ & $\begin{array}{l}\text { Religious theological } \\
\text { identity }\end{array}$ & $\begin{array}{l}\text { Do you consider yourself part of the religious right or } \\
\text { conservative Christian movement or not? } \\
\text { Do you consider yourself part of the religious left or } \\
\text { progressive religious movement or not? }\end{array}$ & $\begin{array}{l}1=\text { Identify as religious } \\
\text { left } \\
2=\text { Identify as religious } \\
\text { right } \\
3=\text { Identify as } \\
\text { something else }\end{array}$ \\
\hline $\begin{array}{l}\text { Public Religion Research Institute } \\
\text { (PRRI)/ Brookings } 2013 \\
\text { Economic Values Survey }\end{array}$ & $\begin{array}{l}\text { Adhere to social } \\
\text { gospel theology }\end{array}$ & $\begin{array}{l}\text { In the Bible, when Jesus and prophets talked about } \\
\text { taking care of the poor, they were primarily talking } \\
\text { about our obligation to create a just society. }\end{array}$ & $\begin{array}{l}0=\text { Does not agree } \\
1=\text { Agree }\end{array}$ \\
\hline $\begin{array}{l}\text { Public Religion Research Institute } \\
\text { (PRRI)/ Brookings } 2013 \\
\text { Economic Values Survey }\end{array}$ & $\begin{array}{l}\text { Adhere to } \\
\text { conservative } \\
\text { religious theology }\end{array}$ & $\begin{array}{l}\text { If enough people had a personal relationship with God, } \\
\text { social problems would take care of themselves }\end{array}$ & $\begin{array}{l}0=\text { Does not agree } \\
1=\text { Agree }\end{array}$ \\
\hline
\end{tabular}




\section{Appendix C}

\section{Health Care Policy Attitude Measures}

\begin{tabular}{|c|c|c|c|}
\hline Study & Variable name & Question wording & Variable measurement \\
\hline $\begin{array}{l}\text { 2000/2009 The Cooperative } \\
\text { Clergy Project }\end{array}$ & $\begin{array}{l}\text { Support universal } \\
\text { health care }\end{array}$ & $\begin{array}{l}\text { We need government-sponsored national health } \\
\text { insurance so that everyone can get adequate } \\
\text { medical care. }\end{array}$ & $\begin{array}{l}0=\text { Does not agree } \\
1=\text { Agree }\end{array}$ \\
\hline $\begin{array}{l}2012 \text { American National } \\
\text { Election Study (ANES) }\end{array}$ & $\begin{array}{l}\text { Approve of the way } \\
\text { President Obama is } \\
\text { handling healthcare }\end{array}$ & $\begin{array}{l}\text { Do you APPROVE or DISAPPROVE of the } \\
\text { way Barack Obama is handling healthcare? }\end{array}$ & $\begin{array}{l}0=\text { Does not approve } \\
1=\text { Approve }\end{array}$ \\
\hline $\begin{array}{l}2012 \text { American National } \\
\text { Election Study (ANES) }\end{array}$ & Support Obamacare & $\begin{array}{l}\text { Do you favor, oppose, or neither favor nor } \\
\text { oppose the healthcare reform law passed in } \\
2010 \text { ? This law requires all Americans to buy } \\
\text { health insurance and requires health insurance } \\
\text { companies to accept everyone? }\end{array}$ & $\begin{array}{l}0=\text { Does not favor } \\
1=\text { Favor }\end{array}$ \\
\hline $\begin{array}{l}2012 \text { American National } \\
\text { Election Study (ANES) }\end{array}$ & $\begin{array}{l}\text { Oppose cutting health } \\
\text { care spending }\end{array}$ & $\begin{array}{l}\text { Thinking about public expenditure on } \\
\text { HEALTH, should there be [much more than } \\
\text { now, somewhat more than now, the same as } \\
\text { now, somewhat less than now, or much less } \\
\text { than now/much less than now, somewhat less } \\
\text { than now, the same as now, somewhat more } \\
\text { than now, or much more than now]? }\end{array}$ & $\begin{array}{l}0=\text { Favor somewhat or much less } \\
\text { healthcare spending } \\
1=\text { Does not somewhat or much } \\
\text { less healthcare spending }\end{array}$ \\
\hline $\begin{array}{l}\text { Public Religion Research } \\
\text { Institute (PRRI)/ Brookings } \\
2013 \text { Economic Values } \\
\text { Survey }\end{array}$ & Support Obamacare & $\begin{array}{l}\text { Do you strongly favor, favor, oppose or strongly } \\
\text { oppose repealing and eliminating the } 2010 \\
\text { health care law? }\end{array}$ & $\begin{array}{l}0=\text { Does not strongly oppose or } \\
\text { oppose repealing and } \\
\text { eliminating the } 2010 \text { health } \\
\text { care law } \\
1 \text { = Oppose or strongly oppose } \\
\text { repealing and eliminating the } \\
2010 \text { health care law. }\end{array}$ \\
\hline $\begin{array}{l}\text { Public Religion Research } \\
\text { Institute (PRRI)/ Brookings } \\
2013 \text { Economic Values } \\
\text { Survey }\end{array}$ & $\begin{array}{l}\text { Support universal } \\
\text { health care }\end{array}$ & $\begin{array}{l}\text { The government should guarantee health } \\
\text { insurance for all citizens, even if it means } \\
\text { raising taxes. }\end{array}$ & $\begin{array}{l}0=\text { Does not agree } \\
1=\text { Agree }\end{array}$ \\
\hline
\end{tabular}


Dr. R. Khari Brown explores how race moderates the relationship between religion and social-political behaviors and attitudes. He uses large survey data sets to examine these relationships. He is a co-investigator of the National Politics Study, a project that survey data on social-political, religious involvement, and political activism.

Dr. Angela Kaiser does ethnographic work on religion and community organizing in urban contexts. Using national survey-based data sets, Dr. Kaiser also explores the relationship between race, religion, and politics. 